Review

\title{
The Application of Cation Exchange Membranes in Electrochemical Systems for Ammonia Recovery from Wastewater
}

\author{
Kai Yang (D) and Mohan Qin*(D) \\ Department of Civil and Environmental Engineering, University of Wisconsin-Madison, Engineering Hall, \\ 1415 Engineering Drive, Madison, WI 53706, USA; kyang288@wisc.edu \\ * Correspondence: mohan.qin@wisc.edu; Tel.: +1-(608)-265-9733
}

check for updates

Citation: Yang, K.; Qin, M. The Application of Cation Exchange Membranes in Electrochemical Systems for Ammonia Recovery from Wastewater. Membranes 2021, 11, 494. https: / / doi.org/10.3390/

membranes11070494

Academic Editor: Orlando Coronell

Received: 1 April 2021

Accepted: 28 June 2021

Published: 30 June 2021

Publisher's Note: MDPI stays neutral with regard to jurisdictional claims in published maps and institutional affiliations.

Copyright: (c) 2021 by the authors. Licensee MDPI, Basel, Switzerland. This article is an open access article distributed under the terms and conditions of the Creative Commons Attribution (CC BY) license (https:// creativecommons.org/licenses/by/ $4.0 /)$.

\begin{abstract}
Electrochemical processes are considered promising technologies for ammonia recovery from wastewater. In electrochemical processes, cation exchange membrane (CEM), which is applied to separate compartments, plays a crucial role in the separation of ammonium nitrogen from wastewater. Here we provide a comprehensive review on the application of CEM in electrochemical systems for ammonia recovery from wastewater. Four kinds of electrochemical systems, including bioelectrochemical systems, electrochemical stripping, membrane electrosorption, and electrodialysis, are introduced. Then we discuss the role CEM plays in these processes for ammonia recovery from wastewater. In addition, we highlight the key performance metrics related to ammonia recovery and properties of CEM membrane. The limitations and key challenges of using CEM for ammonia recovery are also identified and discussed.
\end{abstract}

Keywords: cation exchange membrane (CEM); electrochemical systems; ammonia recovery; nitrogen recovery; wastewater treatment; ion transport

\section{Introduction}

Ammonia $\left(\mathrm{NH}_{3}\right)$ is essential for producing nitrogen fertilizers and is also one of the most common industrial chemicals [1]. Ammonia is synthesized using the energy-intensive Haber-Bosch process [2,3], accounting for more than 1\% of global energy consumption [4]. However, $30 \%$ of ammonia from the Haber-Bosch process is not utilized and ends up in wastewater [5]. Wastewater treatment plants remove ammonium nitrogen by converting it back to nitrogen gas using nitrification-denitrification or anammox process [6], which requires energy consumption and potentially contributes to greenhouse gas emissions. Hence, directly recovering ammonia from wastewater is considered as a promising strategy to save energy from both the Haber-Bosch process for ammonia synthesis and ammonia removal in wastewater treatment plants, as well as produce nitrogen fertilizer for agricultural applications.

Recently, various electrochemical approaches, including bioelectrochemical system (BES), membrane electrosorption (MES), electrochemical stripping (ECS), and electrodialysis (ED), have been used to recover ammonium nitrogen from various types of wastewater (e.g., urine, livestock wastewater, and synthesized wastewater) [7,8]. In the electrochemical systems, electrons are transferred from the anode electrode to the cathode electrode across an external circuit, with either redox reactions or electrosorption occurring at the electrodes. The electrical field drives the ions in solution to transport towards the oppositely charged electrode to maintain electroneutrality [9]. When a cation exchange membrane (CEM) is placed between the anode compartment and cathode compartment, transport of ammonium ions and other cations across the membrane is achieved while the passage of anions is blocked. The transported ammonium ions can then be concentrated and recovered to produce fertilizers. In addition to ammonia recovery, electrochemical processes have 
also been considered as a promising strategy to recover other prime targets, including battery elements, metals, and organic compounds, which have been detailed in previous research [10-13].

CEMs are widely used to separate electrolyte solutions in electrochemical systems. CEM is a dense polymer layer that consists of crosslinked polymer chains fixed with negatively charged groups [14]. Ideally, the fixed functional groups inhibit the transport of anions, while transport of cations, such as ammonium ions and protons, are allowed [15]. Due to the relatively small hydrated ionic size $(0.331 \mathrm{~nm})$ and fast diffusivity in CEM, ammonium ions can be easily transported across the CEM and serve as excellent charge carriers in electrochemical systems $[16,17]$. Hence, the CEM plays a vital role in ammonia recovery from wastewater.

This paper provides a comprehensive review on the application of CEM in electrochemical systems for ammonia recovery from wastewater. Specifically, we introduce four major types of electrochemical processes, including bioelectrochemical systems, electrochemical stripping, membrane electrosorption, and electrodialysis. First, we elucidate the basic principles of these technologies and the contribution of CEMs in achieving ammonia recovery from wastewater. Next, we discuss the mathematical models and equations addressing the ion transport phenomena in the electrochemical processes. We further explain the key parameters characterizing the systems. Then the corresponding CEMs and their properties are summarized and analyzed. The limitations and future perspectives of using CEM for ammonia recovery are identified and discussed.

\section{Electrochemical Systems for Ammonia Recovery}

\subsection{Bioelectrochemical System (BES)}

Bioelectrochemical system (BES) is a group of technologies that rely on the electrochemical interaction of microorganisms and electrodes (Figure 1A) [18-21]. In BES, organic compounds in wastewater are oxidized by exoelectrogens growing on the anode electrode, producing electrons that can be transferred to the cathode electrode through an external circuit [22]. When a cation exchange membrane (CEM) is placed between the anode compartment and cathode compartment, ammonium ions in the wastewater serve as charge carriers in the aqueous phase to maintain the charge balance [23]. In the cathode side, the ammonium ions are converted to ammonia gas due to the high $\mathrm{pH}$ value of the catholyte. The high $\mathrm{pH}$, which has been shown to be sufficient for the conversion of ammonium ions to ammonia, is the result of hydroxide formation from reduction reactions, such as hydrogen evolution reaction (HER) and oxygen reduction reaction (ORR) [24]. The ammonia gas can then be recovered as fertilizers using various kinds of approaches (e.g., direct collection, acid absorption, and gas membrane collection) [25-28]. Ammonia recovery has been achieved in several kinds of BES, including microbial fuel cells (MFCs) and microbial electrolysis cells (MECs) [20,29]. In addition to ammonia recovery, energy can also be recovered in the form of electricity in MFCs autonomously and as hydrogen gas in MECs with an external power supply [30].

\subsection{Electrochemical Stripping (ECS)}

Electrochemical stripping (ECS) is another effective method to extract ammonium nitrogen from wastewater $[8,26]$. Similar to BES, ECS has an anode compartment and a cathode compartment, separated by CEM (Figure 1B). ECS requires an external power source to drive the electrochemical reactions. In ECS, the anode reaction can be an oxygen evolution reaction or hydrogen oxidation reaction, while the cathode reaction is either ORR or HER [8]. Since there is no microbial activity involved, the current density in ECS is not regulated by the microbial metabolism and community structure, allowing for a higher current density and a higher ammonia recovery rate than in BES [31]. However, compared to BES, higher energy consumption in ECS is expected. 


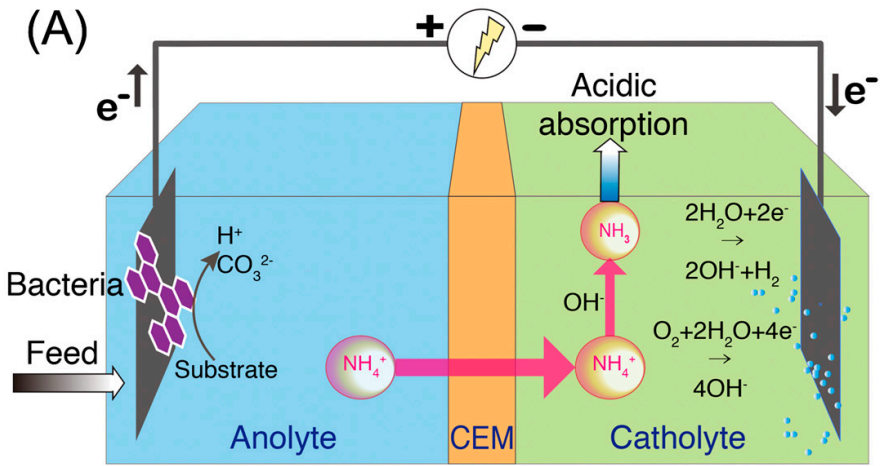

(C)
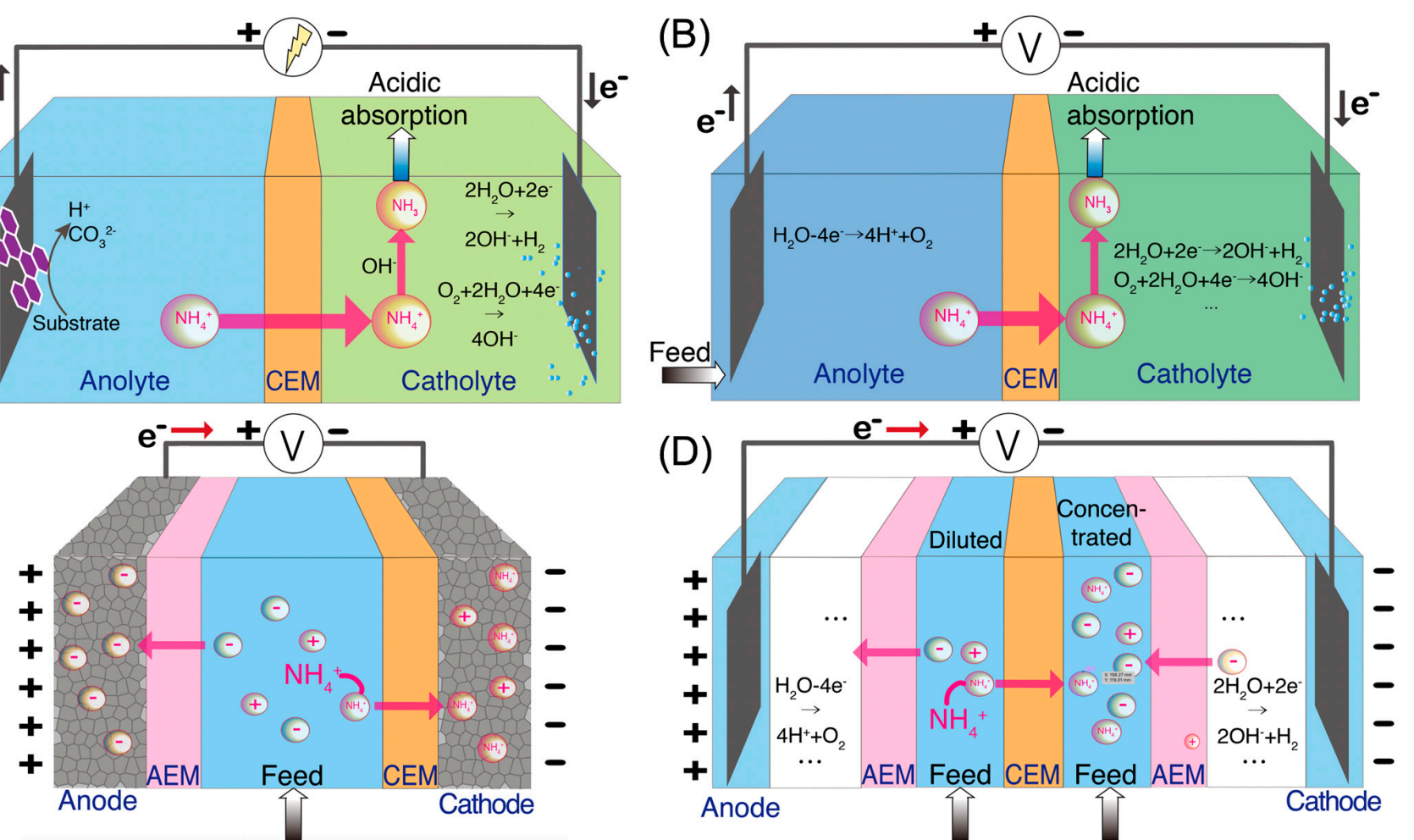

Figure 1. Schematic of four types of ammonia recovery technologies: (A) bioelectrocehmical system (BES), (B) electrochemical stripping (ECS), (C) membrane electrosorption (MES), and (D) electrodialysis (ED).

\subsection{Membrane Electrosorption (MES)}

Membrane electrosorption (MES), which is also known as membrane capacitive deionization (MCDI), can selectively recover ammonium nitrogen from wastewater [32-36]. In the MES, a small voltage $(<1.5 \mathrm{~V})$ is applied between two porous carbon or battery electrodes (Figure 1C). The positively charged electrode and negatively charged electrode are equipped with an anion exchange membrane (AEM) and a CEM, respectively, to prevent the adsorption of co-ions and therefore improve the charge efficiency of MES [37-39]. The electric field generated from the applied potential drives the ions towards the oppositely charged electrodes, where they are immobilized in the micropores of the electrodes [40]. The key feature of MES is the capability of storing the ions in either electrical double layers (EDLs) of the electrode micropores or lattice structures. When wastewater is used as the feed solution, ammonium ions are separated from the feed solution and held at the EDLs or lattice structures of the electrode until the applied voltage is reversed or removed. Once the applied voltage is removed or reversed, the ions are released from the EDLs back into the solution, producing a concentrated stream and regenerating the electrode adsorption sites [41]. By sequentially extracting ammonium from the feed solution and draining ammonium to the concentrated stream, ammonia recovery is achieved.

\subsection{Electrodialysis (ED)}

Same as BES and ECS, electrodialysis (ED) relies on electrochemical redox reactions to generate an electric field and transport ions in solution through ion exchange membranes (IEMs) [42-44]. The main difference is that ED incorporates multiple pairs of ion exchange membranes between the anode and cathode electrodes (Figure 1D). When an electric field is applied, redox reactions occurring at the electrodes drive ions towards the oppositely charged electrodes. As ammonium-rich wastewater is passed through the channels between the alternating CEMs and AEMs, ammonium ions and anions are transported across the CEMs and AEMs, respectively, thereby generating diluted (ammonium removed) and concentrated (ammonium-rich) streams [15,44-46]. In addition, bipolar membranes (BPM) 
have been used together with IEMs in ED to enhance the reactor performance (Figure 2). A BPM is an ion exchange membrane that consists of an AEM layer and a CEM layer. It dissociates water molecules into protons and hydroxide ions in the presence of a strong electrical field [47-50]. The production of concentrated acid and alkali solution by BPM integrated ED facilitates ammonia recovery by the generation of $\mathrm{NH}_{3} \bullet \mathrm{H}_{2} \mathrm{O}$ when treating wastewater [51,52].

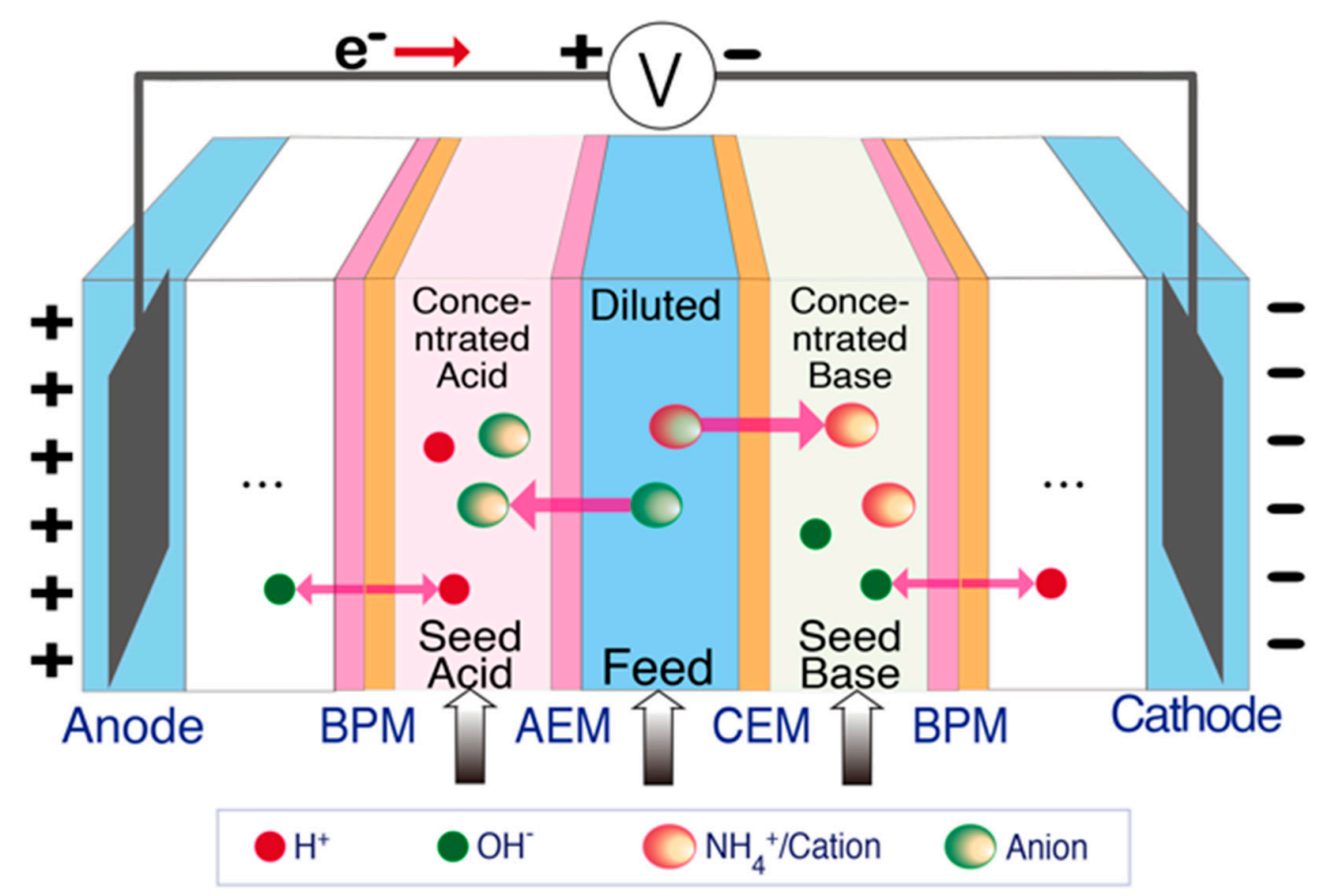

Figure 2. Schematic of BPM integrated ED for ammonia recovery.

\section{Theory of Ion Transport}

Mathematical models have been developed to describe and quantify the transport phenomena in the aforementioned processes [16,53-55], allowing for the prediction of ion concentration profiles and other key parameters that are difficult to measure using experimental study alone (e.g., potential inside the membrane) over a wide range of operating conditions. The mathematical models take into account the ion transport in both aqueous solutions and membranes, membrane properties, and redox reactions on the electrodes. Mass balance and electroneutrality are also included in the model. Usually, water transport through the CEM is neglected as the CEM is relatively thick and thereby has a high hydraulic resistance.

The Nernst Planck equation is widely used to describe ion flux, which is a combination of diffusion and electromigration, in both aqueous solutions and membranes $[54,56,57]$. The Nernst-Planck equation describes the flux of a specific ion as a function of concentration and potential gradient, which is calculated as:

$$
J_{i}=-D_{i} \cdot \frac{\partial c_{i}}{\partial x}-D_{i} \cdot z_{i} \cdot c_{i} \cdot \frac{\partial \phi}{\partial x}
$$

where $J_{i}$ is the flux of ion $i, D_{i}$ is the diffusion coefficient of species $i, z_{i}$ is the ionic charge number, $c_{i}$ is the concentration, $\frac{\partial \phi}{\partial x}$ is the electrical potential gradient, and $x$ is the vertical position from the electrodes.

The models consider mass conservation for all species. For a defined control volume, the mass variation for a specific species is equal to the sum of ion transport flux and the 
accumulation rate due to reactions. For instance, in the catholyte, the mass balance of species $i$ is determined by:

$$
V \cdot \frac{d c_{i}}{d t}=A \cdot J_{i}+\sum_{j} v_{j} \cdot r_{j} \cdot V
$$

where $V$ is the volume of the catholyte, $\frac{d c_{i}}{d t}$ is the concentration variation with time, $A$ is the surface area of control volume, $J_{i}$ is the ion transport flux of species $i, \sum_{j} v_{j} \cdot r_{j} \cdot V$ is the sum of generation or consumption rate of $i$ from each reaction $j, v_{j}$ and $r_{j}$ represents the stoichiometric coefficient and reaction rate of each reaction involving $i$, respectively.

The ion concentration distribution at the membrane-solution interface is governed by Donnan equilibrium. The Donnan equilibrium describes an electrical potential drop at the membrane-solution interface as a function of the concentration of species $i$ at the membrane side and solution side of the interface [58], which is calculated as:

$$
\Delta \phi=-\frac{R T}{z_{i} F} \cdot \ln \frac{c_{i}^{m}}{c_{i}^{s}}
$$

where $R$ is the ideal gas constant, $c_{i}^{m}$ and $c_{i}^{s}$ is the concentration of ion $i$ at the membrane side and at the solution side, respectively.

The charge transfer is always crucial in electrochemical systems. In the mathematical models, electrons flow from anode electrode to cathode electrode across external wires, while ions transport in the aqueous solution between the electrodes. The total charge transferred by ions has to be identical to the charge transferred by electrons, which is calculated as:

$$
I_{\text {ext }}=A_{m} \cdot F \cdot \sum_{i} J_{i} \cdot z_{i}
$$

where $I_{\text {ext }}$ represents external current, $A_{m}$ is the membrane area, $F$ is the Faraday constant, $\sum_{i} J_{i} \cdot z_{i}$ is the sum of charge flux for each species of ion $i$.

Additionally, the individual ion transport behavior is coupled by the law of electroneutrality, which is given by:

$$
\begin{gathered}
\sum z_{i} \cdot c_{i}=0 \\
\sum z_{i} \cdot c_{i}+\omega \cdot X=0
\end{gathered}
$$

where $\omega$ and $X$ represent the charge of the ion exchange membrane and fixed ion concentration in the membrane, respectively. Here $\omega=-1$ is applied for CEM since the charge of fixed groups in CEM is negative.

In BES and ECS, mathematical models based on the abovementioned equations have been applied to understand ammonium transport towards its recovery [16,55]. Previous modeling work has shown that the transport of ammonium ions accounts for approximately $90 \%$ of the total current in a MEC reactor fed with synthetic digestion effluent of livestock waste, indicating that ammonium ions can serve as proton shuttles for the charge transport across the CEM [16]. While the redox reactions acidify and basify anolyte and catholyte, respectively, the transport of ammonia and ammonium ions can buffer the $\mathrm{pH}$ in both anolyte and catholyte, leading to relatively stable $\mathrm{pH}$ values in both sides. The mathematical model was also applied to a MEC reactor to recover ammonia gas from synthetic urine [55]. The simulation results indicate that high current density is beneficial for ammonium transport across the CEM (as shown in Equation (6)), while charge density of CEM membrane has little impact on ammonium transport. When charge density of CEM membrane varies between $0 \mathrm{M}$ and $4 \mathrm{M}$, the transport number of ammonium ions is always close to one, resulting in a large amount of ammonium flux from the anode chamber to the cathode, whereas the transport number of protons is close to zero. One major concern in BES is the back diffusion of ammonia ions from the cathode side to the anode side, which decreases the efficiency of ammonia stripping in the cathode. In other electrochemical systems (i.e., ED and MES), the ammonium transport has not been 
detailed analyzed using mathematical models, although mathematical models have been developed for these processes to capture the ion transport phenomena or estimate the energy consumption $[53,54,59,60]$.

\section{Key Performance Metrics and Membrane Properties}

In electrochemical systems, $\mathrm{pH}$ plays a key role in ammonia recovery. Owing to the redox reactions happening at anode and cathode electrodes, the $\mathrm{pH}$ value in the anode chamber tends to decrease while the $\mathrm{pH}$ in the cathode chamber tends to increase when there are only limited $\mathrm{pH}$ buffer capacities in both sides. The $\mathrm{pH}$ value can not only affect the electrode potential, but also impact the partitioning of ammonium nitrogen between its two forms (i.e., ammonium and ammonia). In BES and ECS fed with ammonia-rich wastewater in the anode chamber, ammonium nitrogen is the major form in the anolyte. In the catholyte, the ammonium nitrogen usually exists as ammonia when the $\mathrm{pH}$ is higher than 10 since the pKa value of ammonia is 9.25 at $25^{\circ} \mathrm{C}$. As a result, the inherent $\mathrm{pH}$ gradient could create a concentration gradient for ammonium ions, which favors the transport of ammonium ions across the CEM membrane.

Among all the key performance metrics, transport number, a dimensionless parameter, is of great importance in electrochemical reactors. Transport number is used to directly describe the amount of ions that move across the membrane. The transport number of an ion species $i$ is defined as the proportion of the charge carried by this kind of ions transported in the electrolyte to the total charge carried by all the ions transported between the electrolytes, which is given by $[7,61,62]$ :

$$
t_{i}=\frac{z_{i} J_{i}}{\sum z_{i} J_{i}}=V \cdot F \cdot z_{i} \cdot \frac{c_{i}(0)-c_{i}(t)}{\int_{0}^{t} I_{t o t} d t}
$$

where $t_{i}$ represents the transport number of $i, J_{i}$ is the flux of the ion $i, z_{i}$ is the charge carried by ion $i, I_{\text {tot }}$ is the total current in the external circuit, $\int_{0}^{t} I_{t o t} d t$ is the sum of charge transferred by the electrons at the external circuit within the time period of $t, V$ is the volume of the electrolyte, $F$ is the Faraday constant, $c_{i}(0)$ and $c_{i}(t)$ are the concentrations at time of zero and time of $t$, respectively. Owing to electroneutrality, the total charge carried by all the ions transported between the electrolytes is supposed to be equal to the external electrical current. In an electrochemical reactor, a larger transport number of ammonium nitrogen indicates more ammonium ions are transported across the CEM per unit current. Ideally, the transport of ammonium ions across the CEM dominates the ion transport across the membrane with a transport number close to one. A higher transport number of ammonium nitrogen benefits the system since it implies that more current is used to transport ammonium ions.

In a BES reactor fed with ammonia-rich livestock wastewater, the transport number of ammonium ions is reported up to 0.49 [7]. In a recent study, the transport efficiency of total ammonia nitrogen (TAN), which is the same as the transport number of TAN, was reported as $92 \%$ in a scaled-up BES system [63]. When calculating the TAN transport efficiency, the transport of ammonium ions and ammonia are lumped, regardless of the partition of ammonia and ammonium ions. The TAN transport number is reported to be affected by the load ratio, which is defined as the ratio of the applied current to the TAN loading rate [64]. By comparing the TAN transport number and the load ratio, the proportion of the current that is used for TAN transport can be calculated, and thus the transport of other cations, such as $\mathrm{Na}^{+}$and $\mathrm{K}^{+}$, can also be evaluated.

Another performance metric is the selectivity of $\mathrm{NH}_{4}{ }^{+}$over another ion $\mathrm{M}^{\mathrm{n}+}$ existing in the solution, which is defined as [53,65]:

$$
\rho\left(\frac{N H_{4}^{+}}{M^{n+}}\right)=\frac{\Delta c_{N H_{4}^{+}} / c_{N H_{4}^{+}, 0}}{\Delta c_{M^{n+}} / c_{M^{n+}, 0}}
$$


where $\Delta c_{N H_{4}^{+}}$and $\Delta c_{M^{n+}}$ are the decreases in $\mathrm{NH}_{4}{ }^{+}$and $\mathrm{M}^{\mathrm{n}+}$ concentrations in the anode chamber, respectively, $c_{\mathrm{NH}_{4}^{+}, 0}$ is the initial concentration of $\mathrm{NH}_{4}{ }^{+}$, and $c_{M^{n+}, 0}$ is the initial concentration of $\mathrm{M}^{\mathrm{n}+}$ in the anode chamber. Selectivity is evaluated when comparing ammonium transport to the transport of other cations in the wastewater (e.g., $\mathrm{Na}^{+}$and $\mathrm{K}^{+}$). For a fixed current, other cations in the anolyte can potentially compete with the ammonium ions for transport across the CEM membrane. A higher selectivity of ammonium ions to other cations implies more portions of ammonium nitrogen are transported across the CEM membrane, therefore potentially improving the removal of ammonium ions from the anolyte (i.e., wastewater). There is only limited discussion on the selectivity of ammonium ions across the CEM membrane in the references. More efforts are needed to investigate and understand ammonium selectivity in electrochemical systems. We note that in electrosorption-based processes, there is another definition of selectivity-the separation factor. The separation factor, which is defined as the ratio of the thermodynamic equilibrium partitions of ion in solid phase (electrodes) to the liquid phase (solution) [66], is used as a metric to quantify the selectivity of the electrodes for electrosorption of the target ions.

The widely used commercial CEMs in electrochemical reactors for ammonia recovery include Nafion N117 (Dupont/Ionpower, Inc., New Castle, DE, USA), CMI-7000 (Membrane International, Membranes International, Inc., Ringwood, NJ, USA), CMH-PP Ralex (Ralex Mega, Straz pod Ralskem, Czech Republic), CEM-Type I and CEM-Type II (FUJIFILM Europe, GmbH, Germany), etc. These membranes have been applied in various kinds of processes for ammonia recovery from wastewater. Table 1 lists the properties of several commonly-used commercial CEMs, including the backbone/branches, thickness, electrical resistance, permselectivity, total exchange capacity, water permeability, thermal resistance, and $\mathrm{pH}$ resistance. All the CEMs listed in Table 1 use sulfonic acid as fixed functional groups and thus allow cations as counter-ions to transport across the membrane, exhibiting excellent properties in transporting cations and blocking water and anions. The backbone and branches vary from tetrafluoroethylene/perfluorovinyl ether to polyamide. The structure of Nafion N117 CEM was reported as a sandwich. In the middle of the sandwich structure lies the embedded core portion, which is either empty or flooded by water/methanol molecules. In contrast, the outer layers of the sandwich model are consist of polymer chains functionalized by sulfonic acid groups $[67,68]$. All CEMs listed in Table 1 can be used in a wide range of $\mathrm{pH}$ values, making CEM suitable for the electrochemical cell due to the acidic environment in anode compartments and basic electrolytes in the cathode. Previous studies have related the properties of CEM to ammonia recovery performance in electrochemical systems. For example, Dykstra et al. reveal that the charge density of the CEM does not impact the transport number of ammonium ions across the membrane [55]. However, since previous studies used various kinds of membranes and system configurations, there is no uniform conclusion of the impact of membrane properties on the electrochemical processes.

Table 1. Properties of commercial cation exchange membranes.

\begin{tabular}{|c|c|c|c|c|c|c|c|c|c|c|}
\hline $\begin{array}{l}\text { Membrane } \\
\text { Name }\end{array}$ & $\begin{array}{l}\text { Company } \\
\text { Name }\end{array}$ & $\begin{array}{l}\text { Backbone } \\
\text { /Branches }\end{array}$ & Thickness & $\begin{array}{l}\text { Electrical } \\
\text { Resistance }\end{array}$ & Permselectivity & $\begin{array}{l}\text { Total } \\
\text { Exchange } \\
\text { Capacity }\end{array}$ & $\begin{array}{l}\text { Water Per- } \\
\text { meability }\end{array}$ & $\begin{array}{l}\text { Thermal } \\
\text { Resistance }\end{array}$ & $\begin{array}{c}\mathrm{pH} \\
\text { Resistance }\end{array}$ & Reference \\
\hline & & & $\mathrm{mm}$ & $\mathrm{Ohm} \cdot \mathrm{cm}^{2}$ & & $\mathrm{meq} / \mathrm{g}$ & $\mathrm{mL} / \mathrm{h} / \mathrm{m}^{2}$ & ${ }^{\circ} \mathrm{C}$ & & \\
\hline $\begin{array}{l}\text { Nafion } \\
\text { N117 }\end{array}$ & Dupo-nt & $\begin{array}{l}\text { tetrafluoroethylene/ } \\
\text { perfluorovinyl } \\
\text { ether }\end{array}$ & 0.183 & 1.725 & $100 \%$ & 0.9 & n.a. ${ }^{*}$ & n.a. & n.a. & [68-70] \\
\hline CMI-7000 & $\begin{array}{l}\text { Membrane } \\
\text { Intl }\end{array}$ & $\begin{array}{c}\text { polystyrene/ } \\
\text { divinylbenzene }\end{array}$ & 0.45 & 30 & $94 \%$ & 1.6 & $\begin{array}{l}32 \text { at } 0.34 \\
\text { bar }\end{array}$ & 90 & $1-10$ & [71] \\
\hline $\begin{array}{l}\text { CMH-PP- } \\
\text { Ralex }\end{array}$ & Mega & $\begin{array}{l}\text { polyester/ } \\
\text { polyethylene }\end{array}$ & 0.45 & 8 & $90 \%$ & n.a. & 0 at 1 bar & 65 & $0-14$ & [72] \\
\hline $\begin{array}{l}\text { CEM- } \\
\text { Type I }\end{array}$ & FUJIFILM & Polyamide & 0.135 & 2.7 & $92 \%$ & n.a. & 13 per bar & 40 & $4-12$ & {$[73,74]$} \\
\hline $\begin{array}{l}\text { CEM- } \\
\text { Type II }\end{array}$ & FUJIFILM & Polyamide & 0.16 & 8 & $96 \%$ & n.a. & 3.5 per bar & 40 & $4-12$ & {$[73,74]$} \\
\hline
\end{tabular}

*: Not applicable. 
The total exchange capacity represents the amount of total sulfonic acid groups available for ion exchange per weight of dry membrane, expressed in milliequivalents per gram (meq/g). It reflects the amount of cation charges that can be carried and conveyed by the CEM. The total exchange capacity affects the fixed charge density, which describes the amount of fixed sulfonic groups per gram of water in the membrane. In addition, permselectivity, which is defined as the ratio of the transfer of electric charges by specific counterions (i.e., $\mathrm{NH}_{4}{ }^{+}$) and the total charge transport across the CEM, is another critical parameter of membrane influenced by both the fixed charge density and the total exchange capacity [75-79].

Water permeability describes the transport of water molecules across the membrane. Kingsbury et al. has demonstrated that water transport impacts the permselectivity of both AEMs and CEMs [62]. In electrochemical systems, water transport across CEMs is negligible, probably owing to the minimal osmotic pressure across CEM and the thickness of CEMs. Since CEM is used to separate the electrolytes and transport specific ions, the CEM with low water permeability is favored in electrochemical systems. However, the sulfonic acid groups attached to the polymer chains in the CEMs increase the hydrophilicity of the membranes, which facilitates the water uptake of a CEM. The water uptake of a typical CEM, Nafion N117, is $11.7 \%$, owing to the hydrophilic portions of the membrane as well as the existence of hydrated ionic groups inside the membrane [69].

The performance of the electrochemical systems for ammonia recovery is summarized and listed in Table 2. The max $\mathrm{NH}_{4}{ }^{+}-\mathrm{N} \mathrm{C}_{0}$ represents the maximum ammonium nitrogen concentration of the influent wastewater. The chemical oxygen demand (COD) of the influent is also listed. The max transport number denotes the highest transport number of ammonium or TAN reached during the electrochemical processes. The efficiency is the ratio of the recovered/removed ammonium to the $\mathrm{NH}_{4}{ }^{+}-\mathrm{N} \mathrm{C}_{0}$. When landfill leachate is fed into a MEC reactor, $65.7 \%$ of ammonium ions can be recovered as ammonium sulfate [80]. With a continuous stirred tank reactor (CSTR) integrated with a submersible microbial desalination cell (SMDC), 40.8\% of ammonia in the anaerobic digestate can be recovered [81]. In MES, gas permeable membranes can be integrated to strip out the ammonia from the cathode side and achieve 93\% ammonia recovery from urine. In addition, the hydrogen evolution reaction occurring in the cathode can be used as substrate in the anode, forming a hydrogen recycling electrochemical system to reduce energy consumption for ammonia recovery [31].

Table 2. Summary of performances of electrochemical systems.

\begin{tabular}{|c|c|c|c|c|c|c|c|c|c|}
\hline $\begin{array}{l}\text { Membrane } \\
\text { Name }\end{array}$ & $\begin{array}{l}\text { System } \\
\text { Type }\end{array}$ & $\begin{array}{c}\text { Max Current } \\
\text { Density or } \\
\text { Voltage }\end{array}$ & Wastewater Type & $\begin{array}{c}\mathrm{Max} \\
\mathrm{NH}_{4}^{+}-\mathrm{N} \\
\mathrm{C}_{0}, \mathrm{gN} / \mathrm{L}\end{array}$ & $\begin{array}{l}\text { COD, } \\
\text { g/L }\end{array}$ & $\begin{array}{c}\text { Max } \\
\text { Transport } \\
\text { Number }\end{array}$ & $\begin{array}{l}\text { Recovery/ } \\
\text { Removal }\end{array}$ & Efficiency & Reference \\
\hline Nafion N117 & BES & $0.5 \mathrm{~A} / \mathrm{m}^{2}$ & Synthetic urine & 4.05 & 0.6 & n.a. * & Recovery & $11.4 \%$ & [25] \\
\hline Nafion N117 & BES & $0.176 \mathrm{~A} / \mathrm{m}^{2}$ & $\begin{array}{l}\text { Synthetic } \\
\text { wastewater }\end{array}$ & 37.9 & 0.0966 & n.a. & Removal & $63.7 \%$ & [83] \\
\hline CMI-7000 & BES & $50 \mathrm{~A} / \mathrm{m}^{2}$ & $\begin{array}{l}\text { Synthetic urine } \\
\text { Activated sludge }\end{array}$ & 5.88 & 7.36 & n.a. & Recovery & $49.5 \%$ & [84] \\
\hline CMI-7000 & BES & $0.6 \mathrm{~A} / \mathrm{m}^{2}$ & $\begin{array}{l}\text { inculated } \\
\text { wastewater }\end{array}$ & n.a. & n.a. & 0.9 & Removal & $85 \%$ & [85] \\
\hline CMI-7000 & BES & $7.6 \mathrm{~A} / \mathrm{m}^{2}$ & $\begin{array}{l}\text { Synthetic ammonia } \\
\text { rich wastewater }\end{array}$ & 6 & n.a. & n.a. & Recovery & $88 \%$ & [81] \\
\hline CMI-7000 & BES & $0.72 \mathrm{~A} / \mathrm{m}^{2}$ & Landfill leachate & 4.54 & 9.175 & n.a. & Recovery & $66 \%$ & [80] \\
\hline CMI-7000 & BES & $0.8 \mathrm{~V}$ & $\begin{array}{c}\text { Synthetic } \\
\text { wastewater }\end{array}$ & 5.111 & 2 & n.a. & Recovery & $99.7 \%$ & [86] \\
\hline $\begin{array}{l}\text { CMH-PP } \\
\text { Ralex }\end{array}$ & BES & $0.917 \mathrm{~A} / \mathrm{m}^{2}$ & $\begin{array}{c}\text { Synthetic } \\
\text { wastewater }\end{array}$ & 4 & 0.64 & n.a. & Recovery & $7 \%$ & [20] \\
\hline Nafion N117 & BES & $93.8 \mathrm{~A} / \mathrm{m}^{2}$ & $\begin{array}{l}\text { Real livestock } \\
\text { wastewater }\end{array}$ & 3 & 30 & 0.492 & Removal & $73 \%$ & [7] \\
\hline CMI-7000 & BES & $4.33 \mathrm{~A} / \mathrm{m}^{2}$ & $\begin{array}{l}\text { Synthetic ammonia } \\
\text { rich wastewater }\end{array}$ & 6 & 2 & n.a. & Recovery & $40.8 \%$ & [87] \\
\hline CMI-7000 & BES & $1.8 \mathrm{~A} / \mathrm{m}^{2}$ & $\begin{array}{l}\text { Synthetic } \\
\text { wastewater }\end{array}$ & 1.19 & 3.23 & 0.489 & Removal & $82 \%$ & [29] \\
\hline
\end{tabular}


Table 2. Cont.

\begin{tabular}{|c|c|c|c|c|c|c|c|c|c|}
\hline $\begin{array}{l}\text { Membrane } \\
\text { Name }\end{array}$ & $\begin{array}{l}\text { System } \\
\text { Type }\end{array}$ & $\begin{array}{l}\text { Max Current } \\
\text { Density or } \\
\text { Voltage }\end{array}$ & Wastewater Type & $\begin{array}{c}\mathrm{Max} \\
\mathrm{NH}_{4}^{+}-\mathrm{N} \\
\mathrm{C}_{0}, \mathrm{gN} / \mathrm{L}\end{array}$ & $\begin{array}{l}\mathrm{COD} \\
\mathrm{g} / \mathrm{L}\end{array}$ & $\begin{array}{c}\text { Max } \\
\text { Transport } \\
\text { Number }\end{array}$ & $\begin{array}{l}\text { Recovery/ } \\
\text { Removal }\end{array}$ & Efficiency & Reference \\
\hline $\begin{array}{l}\text { CMH-PP } \\
\text { Ralex }\end{array}$ & BES & $1.7 \mathrm{~A} / \mathrm{m}^{2}$ & Diluted urine & 0.5 & n.a. & 0.7 & Recovery & $49 \%$ & [88] \\
\hline Nafion N117 & ECS & $50 \mathrm{~A} / \mathrm{m}^{2}$ & $\begin{array}{c}\text { Synthetic } \\
\text { wastewater/urine }\end{array}$ & 3.92 & n.a. & 1 & Removal & $94 \%$ & [64] \\
\hline $\begin{array}{l}\text { Ultrex } \\
\text { CMI-700 }\end{array}$ & ECS & $50 \mathrm{~A} / \mathrm{m}^{2}$ & Synthetic urine & 8.02 & n.a. & 0.55 & Recovery & $57 \%$ & [89] \\
\hline CMI-7000 & ECS & $48 \mathrm{~A} / \mathrm{m}^{2}$ & $\begin{array}{l}\text { Urine/synthetic } \\
\text { urine }\end{array}$ & $5.49 \pm 0.53$ & n.a. & n.a. & Removal & $\begin{array}{c}91.6 \pm \\
2.1 \%\end{array}$ & [90] \\
\hline CMI-7000 & ECS & $100 \mathrm{~A} / \mathrm{m}^{2}$ & $\begin{array}{l}\text { Urine/synthetic } \\
\text { urine }\end{array}$ & 4 & n.a. & n.a. & Recovery & $93 \%$ & [8] \\
\hline CMI-7000 & ECS & $100 \mathrm{~A} / \mathrm{m}^{2}$ & $\begin{array}{c}\text { Synthetic } \\
\text { wastewater }\end{array}$ & $0.03,0.3,3$ & n.a. & n.a. & Recovery & $65 \%$ & [26] \\
\hline Nafion N117 & ECS & $50 \mathrm{~A} / \mathrm{m}^{2}$ & $\begin{array}{c}\text { Urine/synthetic } \\
\text { urine }\end{array}$ & 4 & n.a. & 0.56 & Recovery & $73 \%$ & [31] \\
\hline CEM-Type II & ED & $7 \mathrm{~V}$ & $\begin{array}{l}\text { Activated sludge } \\
\text { inculated } \\
\text { wastewater }\end{array}$ & 4 & n.a. & n.a. & Recovery & $89.6 \%$ & [45] \\
\hline JCM-II-07 & ED & $62 \mathrm{~V}$ & $\begin{array}{c}\text { Synthetic } \\
\text { wastewater }\end{array}$ & 0.6 & n.a. & n.a. & Removal & $\begin{array}{l}95.8- \\
100 \%\end{array}$ & [91] \\
\hline CR67 & ED & $38 \mathrm{~V}$ & $\begin{array}{l}\text { Centrate from } \\
\text { WWTP ** }\end{array}$ & $\begin{array}{c}0.847 \pm \\
0.391\end{array}$ & $\begin{array}{c}0.316 \pm \\
0.044\end{array}$ & 0.4 & Removal & $96-100 \%$ & [43] \\
\hline $\begin{array}{l}\text { IONAC }^{\circledR} \\
\text { MC-3470 }\end{array}$ & ED & $13.4 \mathrm{~A} / \mathrm{m}^{2}$ & $\begin{array}{c}\text { Final effluent of } \\
\text { WWTP }\end{array}$ & $\begin{array}{c}37.04 \pm \\
0.02\end{array}$ & n.a. & n.a. & Removal & $95-98 \%$ & [92] \\
\hline $\begin{array}{l}\text { SK MVK and } \\
\text { SC }\end{array}$ & ED & $\begin{array}{c}6-10 \mathrm{~V}, 45.3 \\
\mathrm{~A} / \mathrm{m}^{2}\end{array}$ & $\begin{array}{l}\text { Synthetic } \\
\text { wastewater }\end{array}$ & 0.5 & n.a. & n.a. & Recovery & $63.2 \%$ & [93] \\
\hline SK & ED & n.a. & $\begin{array}{l}\text { Synthetic } \\
\text { wastewater }\end{array}$ & 1.5 & n.a. & 0.69 & Removal & $85-91 \%$ & [94] \\
\hline CEM-DF-120 & MES & $1.2 \mathrm{~V}$ & $\begin{array}{c}\text { Synthetic } \\
\text { wastewater }\end{array}$ & 0.7 & n.a. & n.a. & Recovery & $63 \%$ & [34] \\
\hline CEM-DF-120 & MES & $1.2 \mathrm{~V}$ & $\begin{array}{l}\text { Synthetic } \\
\text { wastewater }\end{array}$ & 0.02 & n.a. & 0.87 & Removal & $\begin{array}{c}87.00 \pm \\
0.79 \%\end{array}$ & [82] \\
\hline CEM-Type I & MES & $17.2 \mathrm{~A} / \mathrm{m}^{2}$ & $\begin{array}{l}\text { Synthetic } \\
\text { wastewater }\end{array}$ & 0.04 & n.a. & n.a. & Recovery & $78 \%$ & [95] \\
\hline CEM-Type I & MES & $10.4 \mathrm{~A} / \mathrm{m}^{2}$ & $\begin{array}{c}\text { Synthetic } \\
\text { wastewater/urine }\end{array}$ & 0.043 & n.a. & 0.75 & Recovery & $77.8 \%$ & [96] \\
\hline CEM-Type II & MES & $6.8 \mathrm{~A} / \mathrm{m}^{2}$ & $\begin{array}{c}\text { Synthetic } \\
\text { wastewater }\end{array}$ & 0.043 & n.a. & n.a. & Recovery & $74.7 \%$ & [97] \\
\hline CEM-Type II & MES & $6 \mathrm{~A} / \mathrm{m}^{2}$ & $\begin{array}{c}\text { Synthetic } \\
\text { wastewater }\end{array}$ & 0.043 & n.a. & n.a. & Recovery & $32 \%$ & [98] \\
\hline $\begin{array}{l}\text { Neosepta } \\
\text { CMX }\end{array}$ & $\begin{array}{l}\text { BPMED- } \\
\text { MES }\end{array}$ & $300 \mathrm{~A} / \mathrm{m}^{2}$ & $\begin{array}{c}\text { Synthetic } \\
\text { wastewater }\end{array}$ & 0.175 & n.a. & n.a. & Removal & $77 \%$ & [41] \\
\hline CR67 & BPMED & $30 \mathrm{~V}$ & $\begin{array}{l}\text { Centrate from } \\
\text { WWTP }\end{array}$ & $\begin{array}{c}1.189 \pm \\
0.032\end{array}$ & n.a. & 0.86 & Recovery & $88.4 \%$ & [49] \\
\hline $\mathrm{CMB}$ & BPMED & $500 \mathrm{~A} / \mathrm{m}^{2}$ & $\begin{array}{c}\text { Synthetic } \\
\text { wastewater }\end{array}$ & 28 & n.a. & 0.9 & Removal & $96 \%$ & [99] \\
\hline PE 001 & BPMED & $480 \mathrm{~A} / \mathrm{m}^{2}$ & $\begin{array}{c}\text { Synthetic } \\
\text { wastewater }\end{array}$ & 28.8 & n.a. & 0.8 & Recovery & $43.75 \%$ & [52] \\
\hline
\end{tabular}

*: Not applicable; ${ }^{* *}$ : Wastewater treatment plant.

A pilot-scale ED with 30 pairs of CEM-AEMs could remove $96-100 \%$ of ammonia from wastewater and recover a concentrated effluent with an $\mathrm{NH}_{4}{ }^{+}-\mathrm{N}$ concentration of $7.1 \mathrm{~g} / \mathrm{L}$ [43]. Besides, the ED process can be combined with another module to enhance its performance. Liquid-liquid membrane contactors can be integrated with a five cell-pair ED reactor, recovering ammonia directly as liquid fertilizers [45].

In flow-electrode capacitive deionization (FCDI) integrated with a CEM-DF-120 (Tianwei Membrane Technology Co., Ltd., Shandong, China), the efficiency of ammonia removal from municipal wastewater can reach $87 \%$ after system optimization [82]. When a gas permeable membrane is integrated into an FCDI reactor, $78 \%$ of influent ammonia can be recovered from diluted wastewater [34]. In BES/ECS systems, load ratio, $\mathrm{L}_{\mathrm{N}}$, which is the ratio of the applied current and the TAN loading rate, has been proposed to assess the optimal conditions of the reactor for ammonia removal efficiency and energy input. 
When $\mathrm{L}_{\mathrm{N}}$ is larger than 1, excess current is applied compared to the TAN loading, while $\mathrm{L}_{\mathrm{N}}$ lower than 1 represents insufficient current for TAN transport. It was found that $\mathrm{L}_{\mathrm{N}}$ needs to be higher than 1 to achieve the optimal system performance for both synthetic wastewater and urine due to the back diffusion of ammonia from the cathode to the anode compartment [62]. However, load ratio has not been used in electrosorption and ED processes. In the electrochemical process, current and voltage are affected by various parameters, including the rate of the redox reaction at electrodes in redox-driven processes, electrosorption rate in MES, internal resistance, and system design and configurations. Therefore, there is no uniform metrics for all the electrochemical processes as the optimal voltage or current density for ammonia recovery.

\section{Conclusions and Perspectives}

Cation exchange membrane has been extensively applied in electrochemical systems for ammonia recovery from wastewater. In this study, we introduced four kinds of electrochemical systems, including bioelectrochemical systems, electrochemical stripping, electrodialysis, and membrane electrosorption, and discussed the role CEM plays in these processes for ammonia recovery. Besides, the theory used to simulate the ion transport phenomena is also elucidated. The key performance metrics related to ammonia recovery and properties of CEM membrane are then discussed. Despite the progress, there are some challenges we need to address. First, when the electrochemical systems are applied for ammonia recovery, CEMs are in direct contact with ammonia-rich wastewater. Therefore, the degree of ion-ion selectivity is crucial to achieving selective ammonium transport across the membrane. In addition, because of the direct contact of the CEMs and the wastewater, fouling and scaling of the membrane in complex wastewater matrices will be an inevitable and critical issue we need to address in future research. Third, the extraction of dissolved ammonia from the cathode chamber is considered the limiting step for ammonia recovery in electrochemical systems. Hence, we highlight the critical need for incorporation with the ammonia extraction process. Fourth, the energy performance, including energy generation and consumption, of these electrochemical systems for ammonia recovery needs to be systematically analyzed to evaluate if the electrochemical systems using CEM are feasible to recover ammonia from wastewater.

Author Contributions: Conceptualization, K.Y. and M.Q.; methodology, K.Y. and M.Q.; validation, K.Y. and M.Q.; formal analysis, K.Y.; investigation, K.Y.; resources, M.Q.; writing-original draft preparation, K.Y.; writing—review and editing, K.Y. and M.Q.; visualization, K.Y.; supervision, M.Q.; project administration, M.Q.; funding acquisition, M.Q. Both authors have read and agreed to the published version of the manuscript.

Funding: This research received no external funding.

Data Availability Statement: Data sharing not applicable.

Acknowledgments: This work was supported by the startup fund from the Department of Civil and Environmental Engineering, College of Engineering, the Office of the Vice Chancellor for Research and Graduate Education (OVCRGE) at the University of Wisconsin-Madison, and the Wisconsin Alumni Research Foundation (WARF).

Conflicts of Interest: The authors declare no conflict of interest.

\section{References}

1. Rosca, V.; Duca, M.; de Groot, M.T.; Koper, M.T.M. Nitrogen Cycle Electrocatalysis. Chem. Rev. 2009, 109, 2209-2244. [CrossRef]

2. Ertl, G. Elementary Steps in Heterogeneous Catalysis. Angew. Chem. Int. Ed. 1990, 29, 1219-1227. [CrossRef]

3. Jacobsen, C.J.H.; Dahl, S.; Clausen, B.S.; Bahn, S.R.; Logadottir, A.; Nørskov, J.K. Catalyst Design by Interpolation in the Periodic Table: Bimetallic Ammonia Synthesis Catalysts. J. Am. Chem. Soc. 2001, 123, 8404-8405. [CrossRef] [PubMed]

4. Capdevila-Cortada, M. Electrifying the Haber-Bosch. Nat. Catal. 2019, 2, 1055. [CrossRef]

5. Galloway, J.N.; Dentener, F.J; Capone, D.G.; Boyer, E.W.; Howarth, R.W.; Seitzinger, S.P.; Asner, G.P.; Cleveland, C.C.; Green, P.A.; Holland, E.A.; et al. Nitrogen Cycles: Past, Present, and Future. Biogeochemistry 2004, 70, 153-226. [CrossRef] 
6. Van Der Hoek, J.; Duijff, R.; Reinstra, O. Nitrogen Recovery from Wastewater: Possibilities, Competition with Other Resources, and Adaptation Pathways. Sustainability 2018, 10, 4605. [CrossRef]

7. Lee, G.; Kim, K.; Chung, J.; Han, J.-I. Electrochemical ammonia accumulation and recovery from ammonia-rich livestock wastewater. Chemosphere 2021, 270, 128631. [CrossRef]

8. Tarpeh, W.A.; Barazesh, J.M.; Cath, T.Y.; Nelson, K.L. Electrochemical Stripping to Recover Nitrogen from Source-Separated Urine. Environ. Sci. Technol. 2018, 52, 1453-1460. [CrossRef] [PubMed]

9. Kuntke, P.; Sleutels, T.H.J.A.; Arredondo, M.R.; Georg, S.; Barbosa, S.G.; Ter Heijne, A.; Hamelers, H.V.M.; Buisman, C.J.N. (Bio)electrochemical ammonia recovery: Progress and perspectives. Appl. Microbiol. Biotechnol. 2018, 102, 3865-3878. [CrossRef]

10. Chen, S.; Liu, G.; Zhang, R.; Qin, B.; Luo, Y. Development of the Microbial Electrolysis Desalination and Chemical-Production Cell for Desalination as Well as Acid and Alkali Productions. Environ. Sci. Technol. 2012, 46, 2467-2472. [CrossRef] [PubMed]

11. Luo, H.; Jenkins, P.E.; Ren, Z. Concurrent Desalination and Hydrogen Generation Using Microbial Electrolysis and Desalination Cells. Environ. Sci. Technol. 2011, 45, 340-344. [CrossRef]

12. Malik, S.; Drott, E.; Grisdela, P.; Lee, J.; Lee, C.; Lowy, D.A.; Gray, S.; Tender, L.M. A self-assembling self-repairing microbial photoelectrochemical solar cell. Energy Environ. Sci. 2009, 2, 292-298. [CrossRef]

13. Su, X. Electrochemical Separations for Metal Recycling. Electrochem. Soc. Interface 2020, 29, 55-61. [CrossRef]

14. Luo, T.; Abdu, S.; Wessling, M. Selectivity of ion exchange membranes: A review. J. Membr. Sci. 2018, 555, 429-454. [CrossRef]

15. Strathmann, H. Electrodialysis, a mature technology with a multitpude of new applications. Desalination 2010, 264, 268-288. [CrossRef]

16. Liu, Y.; Qin, M.; Luo, S.; He, Z.; Qiao, R. Understanding Ammonium Transport in Bioelectrochemical Systems towards its Recovery. Sci. Rep. 2016, 6, 22547. [CrossRef] [PubMed]

17. Epsztein, R.; Shaulsky, E.; Qin, M.; Elimelech, M. Activation behavior for ion permeation in ion-exchange membranes: Role of ion dehydration in selective transport. J. Membr. Sci. 2019, 580, 316-326. [CrossRef]

18. Cheng, K.Y.; Kaksonen, A.H.; Cord-Ruwisch, R. Ammonia recycling enables sustainable operation of bioelectrochemical systems. Bioresour. Technol. 2013, 143, 25-31. [CrossRef]

19. Cheng, S.; Xing, D.; Call, D.; Logan, B.E. Direct Biological Conversion of Electrical Current into Methane by Electromethanogenesis. Environ. Sci. Technol. 2009, 43, 3953-3958. [CrossRef] [PubMed]

20. Kuntke, P.; Geleji, M.; Bruning, H.; Zeeman, G.; Hamelers, H.; Buisman, C. Effects of ammonium concentration and charge exchange on ammonium recovery from high strength wastewater using a microbial fuel cell. Bioresour. Technol. 2011, 102, 4376-4382. [CrossRef] [PubMed]

21. Logan, B.E.; Call, D.; Cheng, S.; Hamelers, H.V.M.; Sleutels, T.H.J.A.; Jeremiasse, A.W.; Rozendal, R.A. Microbial Electrolysis Cells for High Yield Hydrogen Gas Production from Organic Matter. Environ. Sci. Technol. 2008, 42, 8630-8640. [CrossRef]

22. Wang, H.; Ren, Z. A comprehensive review of microbial electrochemical systems as a platform technology. Biotechnol. Adv. 2013, 31, 1796-1807. [CrossRef] [PubMed]

23. Logan, B.E.; Hamelers, B.; Rozendal, R.; Schröder, U.; Keller, J.; Freguia, S.; Aelterman, P.; Verstraete, W.; Rabaey, K. Microbial Fuel Cells: Methodology and Technologyt. Environ. Sci. Technol. 2006, 40, 5181-5192. [CrossRef] [PubMed]

24. Arredondo, M.R.; Kuntke, P.; Jeremiasse, A.W.; Sleutels, T.H.J.A.; Buisman, C.J.N.; Ter Heijne, A. Bioelectrochemical systems for nitrogen removal and recovery from wastewater. Environ. Sci. Water Res. Technol. 2015, 1, 22-33. [CrossRef]

25. Kuntke, P.; Śmiech, K.; Bruning, H.; Zeeman, G.; Saakes, M.; Sleutels, T.; Hamelers, H.; Buisman, C. Ammonium recovery and energy production from urine by a microbial fuel cell. Water Res. 2012, 46, 2627-2636. [CrossRef]

26. Liu, M.J.; Neo, B.S.; Tarpeh, W.A. Building an operational framework for selective nitrogen recovery via electrochemical stripping. Water Res. 2020, 169, 115226. [CrossRef] [PubMed]

27. Rodrigues, M.; Sleutels, T.; Kuntke, P.; Hoekstra, D.; ter Heijne, A.; Buisman, C.J.; Hamelers, H.V. Exploiting Donnan Dialysis to enhance ammonia recovery in an electrochemical system. Chem. Eng. J. 2020, 395, 125143. [CrossRef]

28. Zhang, Y.; Angelidaki, I. Recovery of ammonia and sulfate from waste streams and bioenergy production via bipolar bioelectrodialysis. Water Res. 2015, 85, 177-184. [CrossRef]

29. Qin, M.; He, Z. Self-Supplied Ammonium Bicarbonate Draw Solute for Achieving Wastewater Treatment and Recovery in a Microbial Electrolysis Cell-Forward Osmosis-Coupled System. Environ. Sci. Technol. Lett. 2014, 1, 437-441. [CrossRef]

30. Liu, H.; Grot, S.; Logan, B.E. Electrochemically Assisted Microbial Production of Hydrogen from Acetate. Environ. Sci. Technol. 2005, 39, 4317-4320. [CrossRef]

31. Kuntke, P.; Arredondo, M.R.; Widyakristi, L.; Ter Heijne, A.; Sleutels, T.H.J.A.; Hamelers, H.V.M.; Buisman, C.J.N. Hydrogen Gas Recycling for Energy Efficient Ammonia Recovery in Electrochemical Systems. Environ. Sci. Technol. 2017, 51, 3110-3116. [CrossRef] [PubMed]

32. Xiao, S.T.A.H. Electrosorption. In Kirk-Othmer Encyclopedia of Chemical Technology; Wiley: Hoboken, NJ, USA, 2016 ; pp. 1-11. [CrossRef]

33. Porada, S.; Zhao, R.; van der Wal, A.; Presser, V.; Biesheuvel, P. Review on the science and technology of water desalination by capacitive deionization. Prog. Mater. Sci. 2013, 58, 1388-1442. [CrossRef]

34. Fang, K.; He, W.; Peng, F.; Wang, K. Ammonia recovery from concentrated solution by designing novel stacked FCDI cell. Sep. Purif. Technol. 2020, 250, 117066. [CrossRef] 
35. Chen, R.; Sheehan, T.; Ng, J.L.; Brucks, M.; Su, X. Capacitive deionization and electrosorption for heavy metal removal. Environ. Sci. Water Res. Technol. 2020, 6, 258-282. [CrossRef]

36. Anderson, M.A.; Cudero, A.L.; Palma, J. Capacitive deionization as an electrochemical means of saving energy and delivering clean water. Comparison to present desalination practices: Will it compete? Electrochim. Acta 2010, 55, 3845-3856. [CrossRef]

37. Kim, Y.-J.; Choi, J.-H. Enhanced desalination efficiency in capacitive deionization with an ion-selective membrane. Sep. Purif. Technol. 2010, 71, 70-75. [CrossRef]

38. Lee, J.-B.; Park, K.-K.; Eum, H.-M.; Lee, C.-W. Desalination of a thermal power plant wastewater by membrane capacitive deionization. Desalination 2006, 196, 125-134. [CrossRef]

39. Li, H.; Gao, Y.; Pan, L.; Zhang, Y.; Chen, Y.; Sun, Z. Electrosorptive desalination by carbon nanotubes and nanofibres electrodes and ion-exchange membranes. Water Res. 2008, 42, 4923-4928. [CrossRef]

40. Helmholtz, H. Helmholtz's theory of double electric layers. J. Franklin Inst. 1883, 115, 310.

41. Suss, M.E.; Porada, S.; Sun, X.; Biesheuvel, P.; Yoon, J.; Presser, V. Water desalination via capacitive deionization: What is it and what can we expect from it? Energy Environ. Sci. 2015, 8, 2296-2319. [CrossRef]

42. Fan, H.; Yip, N.Y. Elucidating conductivity-permselectivity tradeoffs in electrodialysis and reverse electrodialysis by structureproperty analysis of ion-exchange membranes. J. Membr. Sci. 2019, 573, 668-681. [CrossRef]

43. Ward, A.J.; Arola, K.; Brewster, E.T.; Mehta, C.M.; Batstone, D.J. Nutrient recovery from wastewater through pilot scale electrodialysis. Water Res. 2018, 135, 57-65. [CrossRef]

44. Xu, T.; Huang, C. Electrodialysis-based separation technologies: A critical review. AIChE J. 2008, 54, 3147-3159. [CrossRef]

45. Vecino, X.; Reig, M.; Gibert, O.; Valderrama, C.; Cortina, J. Integration of liquid-liquid membrane contactors and electrodialysis for ammonium recovery and concentration as a liquid fertilizer. Chemosphere 2020, 245, 125606. [CrossRef]

46. Shi, L.; Xie, S.; Hu, Z.; Wu, G.; Morrison, L.; Croot, P.; Hu, H.; Zhan, X. Nutrient recovery from pig manure digestate using electrodialysis reversal: Membrane fouling and feasibility of long-term operation. J. Membr. Sci. 2019, 573, 560-569. [CrossRef]

47. Simons, R. Preparation of a high performance bipolar membrane. J. Membr. Sci. 1993, 78, 13-23. [CrossRef]

48. Pärnamäe, R.; Mareev, S.; Nikonenko, V.; Melnikov, S.; Sheldeshov, N.; Zabolotskii, V.; Hamelers, H.; Tedesco, M. Bipolar membranes: A review on principles, latest developments, and applications. J. Membr. Sci. 2021, 617, 118538. [CrossRef]

49. Guo, H.; Yuan, P.; Pavlovic, V.; Barber, J.; Kim, Y. Ammonium sulfate production from wastewater and low-grade sulfuric acid using bipolar- and cation-exchange membranes. J. Clean. Prod. 2021, 285. [CrossRef]

50. Bauer, B.; Gerner, F.; Strathmann, H. Development of bipolar membranes. Desalination 1988, 68, 279-292. [CrossRef]

51. Gao, F.; Wang, L.; Wang, J.; Zhang, H.; Lin, S. Nutrient recovery from treated wastewater by a hybrid electrochemical sequence integrating bipolar membrane electrodialysis and membrane capacitive deionization. Environ. Sci. Water Res. Technol. 2020, 6, 383-391. [CrossRef]

52. Li, Y.; Shi, S.; Cao, H.; Wu, X.; Zhao, Z.; Wang, L. Bipolar membrane electrodialysis for generation of hydrochloric acid and ammonia from simulated ammonium chloride wastewater. Water Res. 2016, 89, 201-209. [CrossRef] [PubMed]

53. Wang, L.; Lin, S. Mechanism of Selective Ion Removal in Membrane Capacitive Deionization for Water Softening. Environ. Sci. Technol. 2019, 53, 5797-5804. [CrossRef]

54. Tedesco, M.; Hamelers, H.; Biesheuvel, P. Nernst-Planck transport theory for (reverse) electrodialysis: I. Effect of co-ion transport through the membranes. J. Membr. Sci. 2016, 510, 370-381. [CrossRef]

55. Dykstra, J.E.; Biesheuvel, P.; Bruning, H.; Ter Heijne, A. Theory of ion transport with fast acid-base equilibrations in bioelectrochemical systems. Phys. Rev. E 2014, 90, 013302. [CrossRef] [PubMed]

56. Teorell, T. Transport Processes and Electrical Phenomena in Ionic Membranes. Prog. Biophys. Biophys. Chem. 1953, 3, 305-369. [CrossRef]

57. Guzmán-Garcia, A.G.; Pintauro, P.N.; Verbrugge, M.W.; Hill, R.F. Development of a space-charge transport model for ion-exchange membranes. AIChE J. 1990, 36, 1061-1074. [CrossRef]

58. Galama, A.; Post, J.; Stuart, M.C.; Biesheuvel, P. Validity of the Boltzmann equation to describe Donnan equilibrium at the membrane-solution interface. J. Membr. Sci. 2013, 442, 131-139. [CrossRef]

59. Wang, L.; Dykstra, J.E.; Lin, S. Energy Efficiency of Capacitive Deionization. Environ. Sci. Technol. 2019, 53, 3366-3378. [CrossRef] [PubMed]

60. Patel, S.K.; Qin, M.; Walker, W.S.; Elimelech, M. Energy Efficiency of Electro-Driven Brackish Water Desalination: Electrodialysis Significantly Outperforms Membrane Capacitive Deionization. Environ. Sci. Technol. 2020, 54, 3663-3677. [CrossRef]

61. Strathmann, H.; Giorno, L.; Drioli, E. An Introduction to Membrane Science and Technology; Wiley-VCH Verlag: Weinheim, Germany, 2011.

62. Kingsbury, R.; Coronell, O. Modeling and validation of concentration dependence of ion exchange membrane permselectivity: Significance of convection and Manning's counter-ion condensation theory. J. Membr. Sci. 2021, 620, 118411. [CrossRef]

63. Zamora, P.; Georgieva, T.; Ter Heijne, A.; Sleutels, T.H.; Jeremiasse, A.W.; Saakes, M.; Buisman, C.J.; Kuntke, P. Ammonia recovery from urine in a scaled-up Microbial Electrolysis Cell. J. Power Sources 2017, 356, 491-499. [CrossRef]

64. Arredondo, M.R.; Kuntke, P.; ter Heijne, A.; Hamelers, H.V.; Buisman, C.J. Load ratio determines the ammonia recovery and energy input of an electrochemical system. Water Res. 2017, 111, 330-337. [CrossRef] [PubMed]

65. He, C.; Ma, J.; Zhang, C.; Song, J.; Waite, T.D. Short-Circuited Closed-Cycle Operation of Flow-Electrode CDI for Brackish Water Softening. Environ. Sci. Technol. 2018, 52, 9350-9360. [CrossRef] [PubMed] 
66. Srimuk, P.; Su, X.; Yoon, J.; Aurbach, D.; Presser, V. Charge-transfer materials for electrochemical water desalination, ion separation and the recovery of elements. Nat. Rev. Mater. 2020, 5, 517-538. [CrossRef]

67. Haubold, H.-G.; Vad, T.; Jungbluth, H.; Hiller, P. Nano structure of NAFION: A SAXS study. Electrochim. Acta 2001, 46, 1559-1563. [CrossRef]

68. Mauritz, K.A.; Moore, R.B. State of Understanding of Nafion. Chem. Rev. 2004, 104, 4535-4586. [CrossRef]

69. Avci, A.H.; Messana, D.A.; Santoro, S.; Tufa, R.A.; Curcio, E.; Di Profio, G.; Fontananova, E. Energy Harvesting from Brines by Reverse Electrodialysis Using Nafion Membranes. Membranes 2020, 10, 168. [CrossRef]

70. Zhang, H.; Hou, J.; Hu, Y.; Wang, P.; Ou, R.; Jiang, L.; Liu, J.Z.; Freeman, B.D.; Hill, A.J.; Wang, H. Ultrafast selective transport of alkali metal ions in metal organic frameworks with subnanometer pores. Sci. Adv. 2018, 4, eaaq0066. [CrossRef]

71. Wang, X.; Wang, L.; Liu, Y.; Duan, W. Ozonation pretreatment for ultrafiltration of the secondary effluent. J. Membr. Sci. 2007, 287, 187-191. [CrossRef]

72. Wang, X.-L.; Tsuru, T.; Togoh, M.; Nakao, S.-I.; Kimura, S. Evaluation of pore structure and electrical properties of nanofiltration membranes. J. Chem. Eng. Jpn. 1995, 28, 186-192. [CrossRef]

73. Sarapulova, V.; Shkorkina, I.; Mareev, S.; Pismenskaya, N.; Kononenko, N.; Larchet, C.; Dammak, L.; Nikonenko, V. Transport Characteristics of Fujifilm Ion-Exchange Membranes as Compared to Homogeneous Membranes AMX and CMX and to Heterogeneous Membranes MK-40 and MA-41. Membranes 2019, 9, 84. [CrossRef] [PubMed]

74. Wang, Z.; Wang, Z.; Lin, S.; Jin, H.; Gao, S.; Zhu, Y.; Jin, J. Nanoparticle-templated nanofiltration membranes for ultrahigh performance desalination. Nat. Commun. 2018, 9, 1-9. [CrossRef]

75. Strathmann, H.; Grabowski, A.; Eigenberger, G. Ion-Exchange Membranes in the Chemical Process Industry. Ind. Eng. Chem. Res. 2013, 52, 10364-10379. [CrossRef]

76. Güler, E.; Zhang, Y.; Saakes, M.; Nijmeijer, K. Tailor-Made Anion-Exchange Membranes for Salinity Gradient Power Generation Using Reverse Electrodialysis. ChemSusChem 2012, 5, 2262-2270. [CrossRef] [PubMed]

77. Güler, E.; Elizen, R.; Vermaas, D.A.; Saakes, M.; Nijmeijer, K. Performance-determining membrane properties in reverse electrodialysis. J. Membr. Sci. 2013, 446, 266-276. [CrossRef]

78. Geise, G.M.; Hickner, M.; Logan, B.E. Ionic Resistance and Permselectivity Tradeoffs in Anion Exchange Membranes. ACS Appl. Mater. Interfaces 2013, 5, 10294-10301. [CrossRef]

79. Bauer, B.; Strathmann, H.; Effenberger, F. Anion-exchange membranes with improved alkaline stability. Desalination 1990, 79, 125-144. [CrossRef]

80. Qin, M.; Molitor, H.; Brazil, B.; Novak, J.T.; He, Z. Recovery of nitrogen and water from landfill leachate by a microbial electrolysis cell-forward osmosis system. Bioresour. Technol. 2016, 200, 485-492. [CrossRef]

81. Zhang, Y.; Angelidaki, I. Submersible microbial desalination cell for simultaneous ammonia recovery and electricity production from anaerobic reactors containing high levels of ammonia. Bioresour. Technol. 2015, 177, 233-239. [CrossRef]

82. Fang, K.; Gong, H.; He, W.; Peng, F.; He, C.; Wang, K. Recovering ammonia from municipal wastewater by flow-electrode capacitive deionization. Chem. Eng. J. 2018, 348, 301-309. [CrossRef]

83. Kim, J.; Kim, B.; Kim, H.; Yun, Z. Effects of ammonium ions from the anolyte within bio-cathode microbial fuel cells on nitrate reduction and current density. Int. Biodeterior. Biodegrad. 2014, 95, 122-126. [CrossRef]

84. Ledezma, P.; Jermakka, J.; Keller, J.; Freguia, S. Recovering Nitrogen as a Solid without Chemical Dosing: Bio-Electroconcentration for Recovery of Nutrients from Urine. Environ. Sci. Technol. Lett. 2017, 4, 119-124. [CrossRef]

85. Cord-Ruwisch, R.; Law, Y.; Cheng, K.Y. Ammonium as a sustainable proton shuttle in bioelectrochemical systems. Bioresour. Technol. 2011, 102, 9691-9696. [CrossRef] [PubMed]

86. Zou, S.; Qin, M.; Moreau, Y.; He, Z. Nutrient-energy-water recovery from synthetic sidestream centrate using a microbial electrolysis cell-Forward osmosis hybrid system. J. Clean. Prod. 2017, 154, 16-25. [CrossRef]

87. Zhang, Y.; Angelidaki, I. Counteracting ammonia inhibition during anaerobic digestion by recovery using submersible microbial desalination cell. Biotechnol. Bioeng. 2015, 112, 1478-1482. [CrossRef] [PubMed]

88. Kuntke, P.; Zamora, P.; Saakes, M.; Buisman, C.J.N.; Hamelers, H.V.M. Gas-permeable hydrophobic tubular membranes for ammonia recovery in bio-electrochemical systems. Environ. Sci. Water Res. Technol. 2016, 2, 261-265. [CrossRef]

89. Luther, A.K.; Desloover, J.; Fennell, D.; Rabaey, K. Electrochemically driven extraction and recovery of ammonia from human urine. Water Res. 2015, 87, 367-377. [CrossRef] [PubMed]

90. Christiaens, M.E.; Gildemyn, S.; Matassa, S.; Ysebaert, T.; De Vrieze, J.; Rabaey, K. Electrochemical Ammonia Recovery from Source-Separated Urine for Microbial Protein Production. Environ. Sci. Technol. 2017, 51, 13143-13150. [CrossRef]

91. Wang, X.; Zhang, X.; Wang, Y.; Du, Y.; Feng, H.; Xu, T. Simultaneous recovery of ammonium and phosphorus via the integration of electrodialysis with struvite reactor. J. Membr. Sci. 2015, 490, 65-71. [CrossRef]

92. Albornoz, L.L.; Marder, L.; Benvenuti, T.; Bernardes, A.M. Electrodialysis applied to the treatment of an university sewage for water recovery. J. Environ. Chem. Eng. 2019, 7, 102982. [CrossRef]

93. Ye, Z.-L.; Ghyselbrecht, K.; Monballiu, A.; Pinoy, L.; Meesschaert, B. Fractionating various nutrient ions for resource recovery from swine wastewater using simultaneous anionic and cationic selective-electrodialysis. Water Res. 2019, 160, 424-434. [CrossRef]

94. van Linden, N.; Bandinu, G.L.; Vermaas, D.A.; Spanjers, H.; van Lier, J.B. Bipolar membrane electrodialysis for energetically competitive ammonium removal and dissolved ammonia production. J. Clean. Prod. 2020, 259, 120788. [CrossRef] 
95. Zhang, C.; Ma, J.; He, D.; Waite, T.D. Capacitive Membrane Stripping for Ammonia Recovery (CapAmm) from Dilute Wastewaters. Environ. Sci. Technol. Lett. 2017, 5, 43-49. [CrossRef]

96. Zhang, C.; Ma, J.; Song, J.; He, C.; Waite, T.D. Continuous Ammonia Recovery from Wastewaters Using an Integrated Capacitive Flow Electrode Membrane Stripping System. Environ. Sci. Technol. 2018, 52, 14275-14285. [CrossRef]

97. Zhang, C.; Ma, J.; Waite, T.D. The impact of absorbents on ammonia recovery in a capacitive membrane stripping system. Chem. Eng. J. 2020, 382, 122851. [CrossRef]

98. Zhang, C.; Ma, J.; Waite, T.D. Ammonia-Rich Solution Production from Wastewaters Using Chemical-Free Flow-Electrode Capacitive Deionization. ACS Sustain. Chem. Eng. 2019, 7, 6480-6485. [CrossRef]

99. Ali, M.; Rakib, M.; Laborie, S.; Viers, P.; Durand, G. Coupling of bipolar membrane electrodialysis and ammonia stripping for direct treatment of wastewaters containing ammonium nitrate. J. Membr. Sci. 2004, 244, 89-96. [CrossRef] 